QUALITY

Volume 8, Nomor 2, 2020, 269-290

\title{
Upaya Menyemai Moderasi Beragama Mahasiswa IAIN Kudus Melalui Paradigma Ilmu Islam Terapan
}

\author{
Nur Salamah \\ IAIN Kudus, Indonesia \\ nursalamah6962@gmail.com \\ Muhammad Arief Nugroho \\ IAIN Kudus, Indonesia \\ ariefnugroho917@gmail.com \\ Puspo Nugroho \\ IAIN Kudus, Indonesia \\ pusponugroho@iainkudus.ac.id
}

\begin{abstract}
Abstrak
Artikel ini bertujuan untuk mengetahui bagaimana Institut Agama Islam Negeri Kudus menyemai moderasi beragama di kalangan mahasiswa dalam menghadapi maraknya radikalisme dan intoleransi. Serta untuk mengetahui paradigma keilmuan seperti apakah yang digunakan dalam menghadapi permasalahan tersebut. Dalam prosesnya penulis menggunakan pendekatan kualitatif. Pengumpulan data dilakukan dengan melakukan studi kepustakaan. Ditemukan adanya tiga langkah strategi penyemaian moderasi beragama berparadigma Islam Terapan di Institut Agama Islam Negeri Kudus diantaranya dengan menjadikan Ilmu Islam Terapan sebagai mata kuliah, membangun Rumah Moderasi, dan menyelenggarakan Kelas IIT. Hasil yang diperoleh dari kajian ini adalah paradigma Ilmu Islam Terapan merupakan pondasi utama dalam menjalankan setiap program kegiatan. Melalui paradigma Islam Terapan dan ketiga strategi penyemaian moderasi beragama tersebut diharapkan dapat membentuk mahasiswa yang berpikir moderat dan bertoleransi tinggi.
\end{abstract}

Kata Kunci: Islam Terapan, Paradigma Amali, Moderasi Beragama 


\begin{abstract}
This article aims to determine how State Islamic Institute of Kudus sow religious moderation among students to against radicalism and intolerance. And to determine which paradigm was used to against that problems. This article uses a qualitative approachment. Data collection is done with library riset technique. There is three steps of strategy to sow religious moderation based to applied islam paradigm in State Islamic Institute of Kudus, among others are make Applied IslamScience as subject, build Rumah Moderasi (Moderation House), and organize an IIT Class. The results obtained from this study is Applied Islam paradigm is the main foundation to operating those strategies. Through Applied Islam paradigm and the sowing strategies of religious moderation are expected to form students can have a moderate thought and high tolerance.
\end{abstract}

Keywords: Applied Islam, Practical paradigm, Religious moderation

\title{
A. Pendahuluan
}

Indonesia adalah negara yang plural, artinya Indonesia merupakan negara yang penuh dengan keberagaman. Suku, etnis, bahasa, budaya dan berbagai macam kepercayaan ada di dalamnya. Semboyan Bhineka Tunggal Ika menggambarkan adanya sebuah persatuan di atas perbedaan-perbedaan yang ada di Indonesia. Dengan mengutamakan kepentingan bersama di atas kepentingan pribadi/golongan diharapkan dapat selalu menjaga persatuan dan kesatuan bangsa. Pluralitas bangsa Indonesia merupakan kekayaan yang teramat berharga. Namun jika tidak dibawa dengan baik akan menjadi ancaman keras bagi bangsa Indonesia (Nugroho, 2012: 300). Pancasila sebagai dasar falsafah negara dan ideologi bangsa menjiwai segala aspek kehidupan bangsa Indonesia, termasuk dalam aspek beragama. Sila pertama Pancasila yang berbunyi Ketuhanan Yang Maha Esa mengantarkan bangsa Indonesia menjadi bangsa yang berkeyakinan. Dalam Undang-Undang Dasar 1945 pasal 29 Ayat 1 dan 2 ditegaskan bahwa Indonesia adalah negara yang berketuhanan. Artinya, Indonesia mewajibkan warga negaranya untuk beragama dengan menjamin keamanan dan ketentraman dalam menjalankan peribadatan. Begitu pula yang diajarkan oleh agama Islam kepada pengikutnya. Islam 
mengajarkan untuk menghargai keyakinan yang dianut oleh umat lain dan tidak memaksa orang masuk ke dalam ajarannya.

Islam memandang keberagaman sebagai sunnatullah. Perbedaan-perbedaan yang ada merupakan ketetapan dari Allah. Menyikapi perbedaan yang ada, Islam mengajarkan pengikutnya untuk berlapang dada, menghargai dan agar saling mengasihi satu sama lain. Selama dalam urusan aqidah tidak dicampur adukkan dengan kepercayaan agama lain, Islam masih memperbolehkan kita berinteraksi dan ber-muamalah secara baik dengan pengikut agama lain. Islam merupakan agama yang penuh dengan toleransi dan ramah bagi seluruh makhluk Allah dalam berbagai urusan. Termasuk dalam urusan sosial masyarakat hingga urusan tatanan negara.

Dewasa ini, berbagai macam peristiwa yang menyelisihkan agama dengan urusan negara sering terjadi di Indonesia. Persoalan yang melibatkan agama cenderung lebih sensitif dan mudah memancing api pertikaian di tengah-tengah masyarakat. Hal tersebut menunjukkan rendahnya rasa toleransi (intoleransi) inter dan antar umat beragama. Sejumlah penelitian masih menunjukkan tingginya angka intoleransi di tengah-tengah masyarakat, diantara lapisan masyarakat yang rawan terserang oleh sikap intoleransi adalah kaum pelajar. Seperti yang tercatat dalam survei, terdapat sekitar 31\% mahasiswa Indonesia bersikap intoleran (Etikasari, 2018: 62). Dampak penyebaran radikalisme tidak boleh dianggap remeh. Upaya preventif terhadap penyebaran paham-paham non Pancasila harus dilakukan untuk menghindari kemungkinan terburuk seperti disintegritas pada bangsa. Merebaknya sikap intoleran di tengah masyarakat dapat mengganggu keseimbangan sosial dan menyerang tatanan negara dari segala sisi, baik dari sisi ekonomi, politik, pendidikan, budaya dan hukum yang dikhawatirkan akan memicu dis integrasi bangsa.

Generasi muda penerus bangsa merupakan sasaran empuk bagi agen-agen propaganda radikal dan intoleransi dalam beragama (Purwanto, 2019: 111). Generasi muda penerus bangsa memiliki rentang usia 12-22 tahun (remaja awal 
hingga remaja akhir). Dalam sudut pandang psikologi perkembangan, pada kurun usia tersebut remaja mengalami masa-masa mencari jati diri (Fhadila, 2017: 21). Melihat maraknya paham-paham radikal atau ideologi non Pancasila yang sedang gencar-gencarnya menyerang Indonesia, remaja tidak luput dari salah satu targetnya. Pergolakan emosional yang tidak stabil pada diri remaja menyebabkan remaja sangat rentan untuk dipengaruhi dan dimasuki dengan paham-paham baru.

Secara empirik, penyebaran paham-paham radikal dan intoleran pada generasi muda akhir-akhir ini kian merebak. Perguruan Tinggi merupakan tempat dimana generasi muda yang disebut "mahasiswa" mencari orientasi masa depannya sehingga mereka cenderung aktif mengembangkan bakat beserta keahlian dengan mengikuti berbagai macam unit kegiatan dan organisasi di kampus. Kelompok radikalisme memanfaatkan peluang tersebut untuk menebarkan ideologi dan paham-paham radikalisme. Di perguruan tinggi tidak terkecuali Perguruan Tinggi Keagamaan Islam (PTKI) tidak menutup kemungkinan untuk dimasuki pahampaham intoleran dan menjadi target dari doktrinisasi paham radikalisme. Gerakan radikalisme biasa menargetkan doktrinisasi kepada para mahasiswa yang sedang gencar-gencarnya mempelajari ilmu agama. Apalagi terhadap para aktifis organisasi yang dapat mereka jadikan sebagai calon kader. Latar belakang semacam ini dimanfaatkan oleh gerakan radikalisme untuk menyebarkan paham-paham yang dimilikinya (Sahri, 2016: 248). Kalam wahyu al-Qur'an dan as-Sunnah sudah membahas secara jelas mengenai pentingnya bersudut pandang moderat dalam beragama. Hal ini dapat diformulasikan ke dalam pencegahan terhadap problematika kehidupan beragama seperti radikalisme dan fanatisme buta (Zamimah, 2018: 79).

Perguruan tinggi merupakan secercah harapan bagi masyarakat untuk membawa perubahan yang lebih baik di masa mendatang. Tanggungjawab dari setiap perguruan tinggi dalam menghadapi situasi semacam ini adalah sebuah keharusan. Perguruan tinggi beserta masyarakat harus bersinergi untuk mewujudkan langkah-langkah preventif terhadap merebaknya paham radikal di 
kalangan mahasiswa. Salah satu bentuk upaya preventif yang dapat dilakukan adalah dengan mensosialisasikan moderasi beragama kepada mahasiswa. Mahasiswa merupakan penyelenggara penting dalam upaya menyemai nilai-nilai moderasi beragama kepada masyarakat. Hal ini menunjukkan bahwa mahasiswa adalah bagian dari garda utama dalam melindungi persatuan bangsa. Bagi masyarakat, mahasiswa adalah agen perubahan (agent of change). Penanaman nilainilai moderasi dalam beragama kepada mahasiswa diwujudkan oleh salah satu Perguruan Tinggi Keagamaan Islam Negeri (PTKIN) yaitu Institut Agama Islam Negeri Kudus (IAIN Kudus) melalui beberapa program yang berlandaskan kajian Ilmu Islam Terapan. Paradigma Ilmu Islam Terapan merupakan sudut pandang baru dalam menumbuhkan Islam moderat di Indonesia.

Kajian terhadap Ilmu Islam Terapan secara umum masih sedikit dilakukan. Artikel ini hendak membahas bagaimana upaya-upaya penyemaian moderasi beragama di kalangan mahasiswa dengan menerapkan Ilmu Islam Terapan oleh Institut Agama Islam Negeri Kudus. Bagaimana mengaplikasikan moderasi beragama masyarakat melalui kajian Ilmu Islam Terapan. Khususnya dalam upaya penyemaian moderasi untuk menjaga kerukunan bangsa serta kedamaian inter dan antar umat beragama yang ada di Indonesia.

Artikel ini akan mengkaji Ilmu Islam Terapan sebagai perwujudan penanaman moderasi beragama kepada mahasiswa di Institut Agama Islam Negeri Kudus. Artikel ini disusun dengan menggunakan pendekatan kualitatif. Teknik pengumpulan data dilakukan melalui studi kepustakaan dengan mengadopsi teoriteori pakar berkenaan dengan moderasi beragama melalui kajian Ilmu Islam Terapan dan menganalisanya. Analisis data yang digunakan adalah analisis deskriptif. Artikel ini memiliki manfaat untuk memberikan paradigma Ilmu Islam Terapan sebagai sudut pandang baru dalam menghadapi problem di masyarakat khususnya radikalisme dan intoleransi. Mengenalkan distingsi institusi terkait ke kancah luar yang pada tahap selanjutnya turut berperan dalam mengembangkan kajian-kajian terhadap pendidikan Islam serta dapat digunakan sebagai referensi 
dan rujukan dalam menanamkan nilai-nilai moderasi beragama kepada mahasiswa. Yang terakhir sebagai upaya untuk mencetak mahasiswa penerus generasi yang berpikir moderat di tengah-tengah keberagaman dan antisipasi terhadap penyebaran radikalisme.

\section{B. Pembahasan}

Kajian studi keislaman harus berani mendialogkan antara Islam ideal dengan realita sosial. Khususnya dalam mengkaji problematika kehidupan umat Islam. Ilmu Islam Terapan menawarkan alternatif pendekatan sosio-religius sebagai solusi problematika yang dihadapi masyarakat. Hal tersebut diyakini mampu mengembangkan sebuah paradigma baru di tengah masyarakat muslim. Pendekatan yang ditawarkan oleh Ilmu Islam Terapan membuktikan sebuah postulat bahwa kalam wahyu al-Qur'an tidak lekang oleh zaman. Al-Qur'an merupakan sumber utama ajaran Islam berfungsi memberikan pedoman dengan sebaik-baiknya. AlQur'an merupakan pedoman bagi umat Islam dalam kehidupan sehari-hari, sebagai indikasi adanya proses transformasi moral dan sosio-moral di dalam masyarakat (Mibtadin, 2019: 96). Dalam pelaksanaannya dilakukan pengkajian terhadap relevansi kalam wahyu untuk diterjemahkan ke dalam setiap realita kehidupan umat manusia. Dengan demikian kalam wahyu al-Qur'an akan senantiasa relevan dengan berbagai macam problematika umat manusia sepanjang zaman (Baedhowi, 2017: 349). Berawal dari hal tersebut, Islam Terapan merupakan sebuah pendekatan baru yang diharapkan dapat menyelesaikan problematika umat, salah satunya adalah problem intoleransi yang terjadi kepada inter dan antar umat beragama.

Ilmu Islam Terapan adalah sebuah ilmu yang menggagas paradigma amali di dalam agama Islam. Paradigma amali merupakan sebuah sudut pandang yang menitikberatkan pada dimensi praktis di dalam kehidupan manusia. Penggagas Paradigma Ilmu Isam Terapan sebagai solusi problematika umat adalah Prof. Muslim A. Kadir. Beliau menekankan bagaimana peran ilmu pengetahuan secara praktis-pragmatik. Gagasan tersebut dilandasi atas keyakinan bahwa ruang lingkup keberagamaan Islam meliputi seluruh aspek kehidupan manusia. Tidak hanya 
berkaitan dengan ritual ibadah semata, tetapi juga sisi mu'amalah seperti ekonomi, politik, sosial-budaya, hukum, pendidikan, sains teknologi, dan lain sebagainya. Oleh karena itu perspektif keilmuan dalam Islam memiliki korelasi yang cukup erat dengan aspek perbuatan yang real atau amali.

Prof. Muslim A. Kadir dalam bukunya yang berjudul Ilmu Islam Terapan (Menggagas Paradigma Amali dalam Agama Islam) menyampaikan bahwa arus paradigma amali tidaklah hanya al-Qur'an dan as-Sunnah, namun juga berupa kenyataan konkret keberagamaan orang beriman. Dengan begitu paradigma amali juga bersumber kepada Islam faktual. Faktualisasi Islam adalah proses mengubah gagasan ideal menjadi faktual atau kenyataan keberagamaan para pemeluk agama. Artinya, paradigma amali bersumber dari kalam wahyu al-Qur'an dan as-Sunnah, namun isinya berpijak di atas nilai-nilai universalitas Islam. Universalitas Islam lebih fleksibel dan ramah ketika berinteraksi dengan realita kehidupan. Sehingga paradigma amali tidak hanya berdasarkan kalam wahyu akan tetapi juga didasari oleh realitas konkret keberagamaan Islam (Kadir, 2003: 32).

Internalisasi nilai-nilai paradigma amali ke dalam ilmu pengetahuan sangat diperlukan. Paradigma amali dibutuhkan sebagai sudut pandang baru dalam memahami ajaran wahyu dan pelaksanaannya. Termasuk ke dalam pencarian solusi dari berbagai macam problematika yang dihadapi umat beragama, khususnya umat Islam dewasa ini. Prosedur kerja paradigma amali dalam hal ini menuntut penjelasan terhadap korelasi antara fenomena keberagaman dengan unsur yang lain. Berdasar pada faktualisasi Islam dengan menampilkan keberagaman kehidupan beragama orang beriman. Berakar dari sana, dihasilkan sebuah teori yang mengkaji prosedur praktis keberagaman itu. Hal ini menjadi tolok ukur pencapaian risalah baik yang berorientasi pada ukhrawi maupun duniawi. Serta menunjukkan bahwa Islam ideal tidak hanya superior dalam teori kewahyuan, melainkan juga unggul secara realitas-empirik. Melalui proses berpikir tersebut, dapat mengembangkan produk ilmu pengetahuan dalam Islam. Begitulah prosedur untuk menemukan suatu teori dalam paradigma amali (Hermanto, 2016:145). 
Salah satu problematika yang di alami masyarakat kini adalah perpecahan inter dan antar umat beragama. Entah disebabkan rendahnya toleransi maupun oleh datangnya paham radikal. Seperti yang dilansir pada laman kolom moderasi beragama oleh Universitas Islam Negeri Sunan Gunung Djati Bandung, bahwa sering terjadi diantara para pemeluk agama dalam mengekspresikan ajaran yang dianut dengan fanatik sehingga terkesan radikal. Agama hanya dipahami secara harfiah atau secara tekstual saja (Darmalaksana, 2019). Oleh karena itu, moderasi beragama menjadi sebuah prioritas. Perguruan Tinggi disini turut berperan dalam usaha menyiapkan pengetahuan praktis mengenai moderasi beragama di dalam kurikulum. Institut Agama Islam Negeri Kudus menjadikan Ilmu Islam Terapan sebagai pengetahuan praktis yang salah satu fungsinya adalah mengenalkan tentang masalah moderasi beragama.

Moderasi dalam bahasa Latin berasal dari kata moderatio yang berarti sedang, tidak lebih dan tidak kurang. Kata moderasi memiliki arti penguasaan diri yang berasal dari sikap kelebihan dan kekurangan. Dalam bahasa Inggris, kata moderation digunakan dalam bentuk pengertian rata-rata pada umunya, baku, inti dan tidak berpihak. Pengertian moderat secara umum yakni mengunggulkan kesetaraan dalam hal kepercayaan, moral, dan watak ketika memandang orang lain sebagai seorang individu atau sebuah kelompok, maupun ketika berhadapan dengan institusi negara. Dalam bahasa Arab, moderasi disebut dengan kata wasath atau wasathiyah, yang bermakna sama dengan kata tawassuth (tengah-tengah), I'tidal (adil) dan tawazun (berimbang). Dan wasith merupakan sebutan untuk seseorang yang menerapkan prinsip wasathiyah. Dalam bahasa Indonesia wasit mempunyai tiga pengertian, pertama, penengah, perantara dalam suatu urusan. Kedua, pelerai atau mediator, pendamai antara yang berselisih. Ketiga, pemimpin di dalam sebuah pertandingan (Kemenag RI, 2019).

Moderasi agama merupakan sikap beragama yang seimbang antara keyakinan terhadap agama sendiri (eksklusif) dan penghormatan terhadap orang lain yang berbeda keyakinan (inklusif). Untuk menghindari sikap ekstrem dan 
fanatik berlebihan terhadap suatu golongan/aliran serta sikap revolusioner dibutuhkan sebagai jalan tengah atau keseimbangan dalam praktik beragama. Moderasi beragama menjadi kunci terbentuknya budaya toleransi dan kerukunan di tingkat lokal, nasional, dan global. Moderasi dalam beragama menolak pahampaham seperti ekstremisme dan liberalisme merupakan kunci keseimbangan untuk melestarikan peradaban dan terciptanya perdamaian dalam aktivitas beragama. Dengan cara ini umat beragama dapat memandang orang lain dengan sikap penuh hormat, menerima perbedaan, serta dapat hidup berdampingan dengan baik. Moderasi beragama menjadi suatu keharusan untuk Indonesia yang dihuni oleh lapisan masyarakat yang multikultural (Kemenag RI, 2019).

Moderasi agama dalam wujud toleransi antarumat beragama memiliki batasan yang tidak boleh dilewati, yaitu perihal aqidah. Aqidah merupakan suatu perkara yang paten dan tidak bisa dinegosiasikan. Toleransi yang dimaksud dalam Islam adalah dalam bidang interaksi dan muamalah dengan baik kepada nonmuslim. Toleransi tanpa campur tangan terhadap hari raya dan peribadatan mereka. Islam sangatlah tegas dalam perihal toleransi antar umat beragama. Seperti yang difirmankan dalam (Q.S. al-Kafirun ayat 6) yang artinya: "Untukmu agamamu dan untukku agamaku”

Islam merupakan agama yang ramah dan tidak memaksa orang untuk beriman ke dalamnya. Allah menghendaki atas keimanan seseorang dan tidak berimannya seseorang. Manusia diberi kebebasan untuk menentukan pilihan. jika Allah menghendaki seluruh dunia beriman maka tentulah semuanya akan beriman. Namun di dalam QS Yunus ayat 99-100 disebutkan, Allah berfirman yang artinya: "Dan jika Tuhanmu menghendaki, tentulah beriman semua orang di muka bumi seluruhnya. Maka apakah kamu (hendak) memaksa manusia supaya mereka menjadi orang-orang yang beriman semua? Dan tidak ada seorangpun akan beriman kecuali dengan izin Allah; dan Allah menimpakan kemurkaan kepada orang-orang yang tidak mempergunakan akalnya."Berdasarkan ayat tersebut, Islam merupakan agama yang ramah untuk kehidupan manusia. Islam mengajarkan 
pengikutnya untuk bersikap moderat dan adil terhadap sesame makhluk Allah (Mursyid, 2016: 38).

Islam berpegang teguh kepada prinsip rahmatan lil 'aalaamiin yang bermakna bahwa Islam membawa rahmat bagi seluruh alam. Islam datang untuk membawa ketenangan dan tidak menimbulkan perselisihan baik secara intern (antar umat islam) maupun ekstern (dengan umat lain). Untuk itu dalam kajian Ilmu Islam Terapan, paradigma amali merupakan perwujudan dari prinsip rahmatan lil 'aalaamiin. Memahami Islam itu dari kalam wahyu al-Qur'an dan as-Sunnah. Tidak cukup jika ditelaah secara linguistik saja. Al-Qur'an merupakan teks yang hidup dan terbuka. Maka dari itu memahami al-Qur'an diperlukan respon yang komunikatif (Hasib, 2014: 320). Berpegang teguh kepada al-Qur'an, as-Sunnah dan secara aplikatif menerapkannya dalam kehidupan sehari-hari bersamaan dengan nilai-nilai universalitas Islam. Salah satu bentuk perwujudan paradigma amali adalah dengan menjalankan moderasi beragama. Berlandaskan pada prinsip bahwa ajaran Islam berlaku untuk semua manusia, Islam pun harus memerhatikan mereka yang tidak memeluk agama Islam.

Sebagaimana visi dan misi institusi, Institut Agama Islam Negeri Kudus telah dikenal sebagai Gerbang Pengembangan Islam Terapan (Humanity, Applicability, Productivity), maksudnya adalah menyelenggarakan tridharma perguruan tinggi untuk mencetak output (lulusan) yang humanis, aplikatif dan produktif dengan Islam terapan. Seperti yang terlampir di dalam Pedoman Akademik Program Sarjana IAIN Kudus Tahun 2019 dikemukakan bahwa visi dari Institut Agama Islam Negeri Kudus adalah Menjadi Perguruan Tinggi Islam Unggul di Bidang Pengembangan Ilmu Islam Terapan. Strategi yang digunakan dalam mewujudkan visi tersebut adalah dengan menyelenggarakan pembelajaran yang aktif, intregatif, dan kontekstual dengan berparadigma Islam Terapan berwawasan keindonesiaan dan berorientasi kepada kearifan lokal. Secara umum upaya penyemaian moderasi beragama kepada para mahasiswa sudah dilakukan oleh Institut Agama Islam Negeri Kudus. Dengan paradigma Ilmu Islam Terapan, 
Institut Agama Islam Negeri Kudus melakukan beberapa upaya diantaranya adalah dengan menyelenggarakan pembelajaran mata kuliah Ilmu Islam Terapan, kemudian membangun Rumah Moderasi berparadigma Islam Terapan dan dibentuknya Kelas IIT (Ilmu Islam Terapan) bersama Prof. Muslim A. Kadir selaku pengusung konsep Ilmu Islam Terapan. Langkah-langkah tersebut diharapkan dapat menumbuhkan kultur toleransi dan cara berpikir moderat di kalangan mahasiswa dan seluruh civitas akademika.

\section{Ilmu Islam Terapan Sebagai Mata Kuliah}

Institut Agama Islam Negeri Kudus mulai berpedoman pada Kerangka Kualifikasi Nasional Indonesia (KKNI) semenjak tahun 2017. Saat itu Istititut Agama Islam Negeri Kudus masih berstatus Sekolah Tinggi Agama Islam Negeri (STAIN). Penggunaan KKNI merupakan mandate dari Undang-Undang Sisidiknas No. 20 Tahun 2003, PP No. 14 Tahun 2014 tentang Pengelolaan dan Penyelenggaraan Pendidikan dan Permenristekdikti No. 44 Tahun 2015 tentang Standar Nasional Pendidikan Tinggi. Rancangan kurikulum yang dianut oleh Institut Agama Islam Negeri Kudus mengacu pada KKNI dengan spesifikasi visi, misi dan tujuan institusi (IAIN Kudus, 2019).

Ilmu Islam Terapan menjadi salah satu mata kuliah inti di Institut Agama Islam Negeri Kudus. Ilmu Islam Terapan merupakan mata kuliah ciri khas institusi. Mata kuliah ciri khas institusi adalah upaya untuk mengembangkan kompetensi yang disesuaikan dengan ciri khas institusi yang bersangkutan, sama halnya dengan muatan lokal (mulok). Dengan demikian, menjadikan Ilmu Islam Terapan sebagai mata kuliah ciri khas institusi merupakan langkah yang sangat tepat untuk menindaklanjuti Kudus sebagai kota yang penuh dengan toleransi. Sunan Kudus membumikan nilai nilai harmonisasi dan toleransi bersama dengan bukti-bukti peninggalannya sebagai perwujudan dari kuatnya hidup toleransi antar umat beragama yakni berupa Menara Kudus, tradisi mengganti hewan qurban sapi menjadi kerbau dimana dalam tradisi masyarakat hindu sapi diyakini sebagai hewan suci, adanya kepercayaan terhadap air suci seperti sendhang dan banyu panguripan 
serta bentuk tradisi lainya menambah kekayaan harmonisasi kota Kudus. Prof. Muslim A. Kadir berpendapat penguatan Ilmu Islam Terapan sebagai upaya menyemai moderasi di kalangan mahasiswa memandang bahwa gagasan ini merupakan rumusan standar epistemologi untuk melaksanakan al-Qur'an dan asSunnah sesuai dengan mahiah-nya dipahami dan dimaknai dengan ketulusan akademik (Kadir, 2020).

Mata kuliah Ilmu Islam Terapan memiliki bobot tiga satuan kredit semester (3 SKS). Setiap fakultas dan program studi mendapatkan mata kuliah Ilmu Islam Terapan. Ilmu Islam Terapan sebagai mata kuliah wajib institusi mengkaji tentang ilmu-ilmu yang bersifat amali. Di dalam kajian Ilmu Islam Terapan terdapat berbagai bentuk pembahasan, diantaranya adalah beriman kepada Allah sebagai penghayatan fungsional, al-Qur'an sebagai wahyu, as-Sunnah sebagai keberagaman konkret, keberagamaan Islam, din dan tadayyun serta berbagai kajian fiqh seperti ibadah dan mu'amalah. Hal ini selaras dengan penerapan al-Qur'an dan as-Sunnah di dalam kehidupan manusia dengan menjalankan prinsip-prinsip universalitas Islam. Proses pembelajaran didukung oleh buku karya Prof. Muslim A. Kadir yang berjudul Ilmu Islam Terapan (Menggagas Paradigma Amali dalam Agama Islam) dan Buku Dasar-Dasar Praktikum Keberagamaan dalam Islam.

\section{Rumah Moderasi Beragama}

Lebih lanjut mengenai upaya penyemaian moderasi beragama di kalangan mahasiswa. IAIN Kudus sebagai salah satu PTKIN di Indonesia menghadirkan paradigma keilmuan berbasis Ilmu islam terapan. Ilmu Islam Terapan menjadi ruh dalam setiap program kegiatan. Di antara beberapa program yang lebih khusus fokus pada deradikalisasi adalah berkaitan dengan upaya menyemai moderasi beragama berparadigma Islam terapan di kalangan mahasiswa dimana institusi sangat mensuport dengan didirikannya Rumah Moderasi Beragama. Rumah Moderasi beragama merupakan wadah penyemaian, edukasi, konseling dan penguatan nilai-nilai moderasi beragama di lingkungan akademik. Hal tersebut ditegaskan dalam Sambutan Rektor IAIN Kudus Dr. H Mundakir, M.Ag pada 
Launching Rumah Moderasi. Penyemaian moderasi beragama di lingkungan akademik merupakan prventif terhadap penyebaran paham radikalisme di kalangan akademisi khususnya mahasiswa. Untuk itu, Institut Agama Islam Negeri Kudus mengedepankan pemikiran yang bersifat moderat dalam kehidupan sehari-hari, membangun budaya gotong-royong dan kebersamaan. Dilansir oleh kemenag.go.id dasar konstitusi berdirinya Rumah Moderasi merupakan kebijakan Kementerian Agama RI dalam Surat Edaran DIRJEN PENDIS No. B3663.1/Dj.I/BA.02/10/2019 tentang instruksi kepada seluruh Perguruan Tinggi Agama Islam (PTKI) untuk memiliki Rumah Moderasi Beragama (Direktorat Jendral Pendidikan Islam Kementrian Agama RI, 2020).

Rumah moderasi selanjutnya menjadi wadah pelatihan moderasi beragama, khususnya bagi seluruh civitas akademika dari sebuah lembaga/institusi pendidikan. Selain itu, Rumah Moderasi pula berperan dalam analisis strategis terhadap pengembangan moderasi beragama di lingkungan masyarakat. Menimbang bahwa Indonesia merupakan negara berketuhanan dengan berbagai keyakinan yang ada, konsep moderasi tidak hanya diperuntukkan bagi umat Islam selaku mayoritas. Moderasi beragama harus ditanamkan kepada semua penganut agama menimbang potensi perpecahan itu ada pada semua agama. Rumah moderasi berfungsi sebagai pusat penelitian dan informasi moderasi beragama bagi seluruh umat beragama yang ada di Indonesia.

Launching Rumah Moderasi oleh Institut Agama Islam Negeri Kudus dilaksanakan pada tanggal 14 Februari 2020 bersamaan dengan diselenggarakannya seminar nasional keagamaan yang bertajuk "Refleksi Moderasi Beragama di Kudus dalam Bingkai Ilmu Islam Terapan”. Secara resmi Rumah Moderasi disahkan oleh Wakil Menteri Agama RI Drs. H. Zainut Tauhid Sa'adi bersama rektor Institut Agama Islam Negeri Kudus beserta jajarannya. Dengan adanya Rumah Moderasi di lingkungan Institut Agama Islam Negeri Kudus diharapkan dapat menciptakan lingkungan kampus yang religius dan penuh toleransi serta mencetak para intelektual profesional yang mampu menyelesaikan problematika masyarakat 
terutama mengenai isu keagamaan. Agama dan negara bukanlah hal yang perlu dipertentangkan. Semua memiliki hak sebagai umat beragama sekaligus warga negara. Seperti yang tercantum pada pasal 27 ayat 1 Undang-Undang Dasar 1945 bahwa semua memiliki keududukan yang sama di hadapan hukum. Dengan adanya Rumah Moderasi, diharapkan mampu mencetak kader-kader yang mencintai agama sekaligus mencintai bangsa dan negara serta menjaga perdamaian inter dan antar umat beragama di Indonesia.

\section{Kajian Ilmu Islam Terapan (Kajian IIT)}

Menindaklanjuti keberadaan Rumah Moderasi Beragama oleh Institut Agama Islam Negeri Kudus adalah dengan diselenggarakannya Kajian Ilmu Islam Terapan (selanjutnya Kajian IIT) bersama Prof. Muslim A. Kadir sebagai narasumber utama sekaligus pengusung konsep Ilmu Islam Terapan. Pada prosesnya kajian Ilmu Islam terapan terbagi menjadi dua, kajian yang bersifat kelas IIT dikhususkan kepada kalangan mahasiswa, dan Kajian rutin setiap Rabu pagi dikhususkan untuk dosen.

Terkhusus pada kelas IIT mahasiswa berbeda dengan Mata kuliah Ilmu Islam Terapan yang proses pembelajarannya dilakukan di ruang kelas dan masuk dalam kurikulum, Kelas IIT merupakan program baru di luar jam perkuliahan sehingga tidak memiliki bobot SKS (Satuan Kredit Semester). Program ini berisikan kegiatan-kegiatan diantaranya adalah diadakannya dialog interaktif antara mahasiswa dengan narasumber utama mengangkat tema-tema yang berkaitan dengan Ilmu Islam Terapan serta pengaplikasiannya di dalam kehidupan seharihari. Kegiatan selanjutnya adalah meresensi sedikit demi sedikit dari karya-karya Prof. Muslim A. Kadir yang bertajuk Ilmu Islam Terapan.

Program ini melibatkan mahasiswa untuk terjun secara langsung dalam upaya merealisasikan lingkungan kampus yang moderat dan religius. Dalam mewujudkan program Kelas IIT, Institut Agama Islam Negeri Kudus menggandeng salah satu Unit Kegiatan Mahasiswa Komunitas Pecinta Nalar (UKM KPN) sebagai 
koordinator pelaksanaan kelas IIT setiap Jum'at sore. Kelas IIT merupakan langkah nyata untuk mengenalkan Visi IAIN Kudus serta menyemai moderasi beragama pada mahasiswa Institut Agama Islam Negeri Kudus. Selaras dengan tujuan kelas IIT adalah untuk membangun paradigma berfikir mahasiswa menjadi open minded terhadap moderasi beragama, menyadarkan mahasiswa urgensi mempelajari moderasi beragama sebagai bekal terjun di masyarakat yang multicultural (Yulia, 2020).

Kelas IIT ibarat katalisator dalam proses penyemaian moderasi beragama di lingkungan perguruan tinggi. Mahasiswa merupakan sebagian besar yang mengisi populasi suatu perguruan tinggi. Dengan melibatkan mahasiswa di dalam program penyemaian moderasi beragama dapat meningkatkan efektivitas keberhasilan program tersebut. Mahasiswa merupakan akademisi muda yang berpikir kritis dengan semangat yang membara. Dengan melibatkan oknum mahasiswa dalam suatu program kampus akan sangat mudah untuk menyebar kepada mahasiswa lainnya. Dengan demikian, kultur moderasi beragama dapat dijalankan pada suatu lembaga perguruan tinggi. Bekerjasama dengan unit kegiatan mahasiswa dalam upaya internalisasi nilai-nilai moderasi merupakan langkah preventif untuk menjaga mahasiswa dari oknum-oknum yang memiliki paham radikal dan intoleransi.

Proses penyemaian moderasi beragama bagi mahasiswa Institut Agama Islam Negeri Kudus melalui paradigma Ilmu Islam Terapan diwujudkan ke dalam tiga upaya yaitu dengan menjadikan Ilmu Islam Terapan sebagai mata kuliah resmi, kemudian mendirikan Rumah Moderasi dan menyelenggarakan Kelas IIT. Bersamaan dengan semua itu terdapat faktor-faktor yang mendukung keberhasilan masing-masing program. Contohnya dengan memanfaatkan KKNI dalam memaksimalkan potensi dan kekhasan institusi dalam mata kuliah Ilmu Islam Terapan. Selanjutnya adalah dengan diadakannya sebuah seminar (conference) bertajuk moderasi beragama bersamaan dengan mendirikan Rumah Moderasi, kemudian pengadaan Kelas IIT dengan mengadakan kerjasama dengan mahasiswa. 
Moderasi beragama adalah kebutuhan konkret bangsa. Diperlukan suatu formasi kerja untuk menyiapkannya. Sementara melalui prosedur kerja Ilmu Islam Terapan dihasilkan sebuah teknologi moderasi beragama yang berdasar pada kulliyat atau universalitas kalam wahyu al-Qur'an dan wujud konkret as-Sunnah yang kemudian dikembangkan menjadi sains dan oleh teori praktek menjadi sebuah teknik untuk moderasi beragama. Dalam prakteknya, moderasi beragama di Institut Agama Islam Negeri Kudus meliputi adab sopan santun terhadap seluruh warga institusi, upaya menjaga lingkungan tetap kondusif seperti menjaga kebersihan dengan tidak membuang sampah sembarangan, musyawarah seperti yang direpresentasikan oleh organisasi-organisasi internal maupun eksternal, mengangkat kajian-kajian yang bertajuk moderasi beragama dalam seminar nasional, dan lain-lain. Teknologi moderasi beragama berdasar pada prinsip kulliyat digeneralisasikan melalui upaya-upaya yang telah disebutkan di atas.

Upaya dilakukan Institut Agama Islam Negeri Kudus sebagai bentuk rasa tanggungjawab atas kewajiban seluruh lapisan masyakat dalam menjaga persatuan dan keutuhan Negara Kesatuan Republik Indonesia (NKRI). Institut Agama Islam Negeri Kudus benar-benar mengambil peran Perguruan Tinggi sebagai ladang untuk mengoptimalkan akademisi terjun dalam menghadapi problematika masyarakat. Upaya tersebut diwujudkan melalui penyemaian moderasi beragama kepada masyarakat melalui mahasiswa. Mahasiswa di masa yang akan datang menjadi generasi baru yang melanjutkan struktur sosial tatanan masyarakat. Membentuk mahasiswa yang berpikir moderat dengan berpegang teguh kepada kalam wahyu al-Qur'an dan as-Sunnah akan membangun peradaban bangsa yang stabil lagi kuat. Dengan begitu Indonesia tidak akan mudah dimasuki oleh pahampaham radikal intoleran dan menghindarkan diri dari perpecahan dalam masyarakat multikultural.

Menyebarkan cara berpikir moderat kepada masyarakat dapat dilakukan melalui pendekatan religius sekaligus pendekatan multicultural (Akhmadi 2019: 53). Porsi pendekatan religius harus lebih besar daripada pendekatan multikultural. 
Hal ini dikarenakan agama merupakan patokan dalam hidup sehari-hari umat. Selanjutnya melalui pendekatan multikultural yang mengedepankan rasa hormat terhadap perbedaan yang merupakan sunnatullah. Moderasi beragama identik dengan tenggang rasa, saling menghargai dan sikap mentolerir antarsesama makhluk. Salah satu bentuk dari kontekstualisasi moderasi beragama dalam masyarakat adalah dengan menghargai perbedaan kultur tradisi dari masing-masing lapisan masyarakat. Seperti halnya tradisi penggantian hewan qurban dari sapi menjadi kerbau di Kudus. Kultur tersebut merupakan peninggalan dari ajaran Sunan Kudus. Di masa lampau, Kudus dihuni oleh masyarakat hindu. Kemudian Sunan Kudus datang menyebarkan ajaran Islam. Sebagai bentuk penghormatan terhadap umat Hindu, dalam perayaan ibadah qurban Sunan Kudus mengganti hewan qurban sapi menjadi kerbau. Karena sapi merupakan hewan yang disucikan oleh umat Hindu. Begitulah contoh moderasi agama dalam wujud toleransi yang diajarkan oleh Sunan Kudus. Kultur tersebut masih berjalan hingga detik ini. Selama melakukan ibadah qurban, warga Kudus mengganti hewan qurban sapi menjadi kerbau (Kadir \& Ihsan, 2019:89).

Menerapkan moderasi beragama pada masyarakat merupakan tugas penting bagi para akademisi termasuk mahasiswa. Terlebih lagi bagi mahasiswa Institut Agama Islam Negeri Kudus yang sejak awal sudah diarahkan untuk menghadapi masyarakat dengan berbagai keragaman yang ada di dalamnya. Kajian terhadap Ilmu Islam Terapan secara mendalam akhirnya dapat memberikan impact kepada masyarakat. Mahasiswa diajari untuk ber-tafaqquh fiddiin menguasai dan mahir dalam ilmu agama khususnya dalam memahami dan menelaah kalam wahyu alQur'an dan as-Sunnah. Hal tersebut untuk diaplikasikan dalam kehidupan seharihari dalam wujud interaksi komunikasi dan urusan ber-muamalah. Dalam prakterknya, dilakukan dengan bertumpu kepada sudut pandang berpikir yang moderat. Hal-hal yang dapat dilakukan mahasiswa dalam menyemai moderasi beragama di dalam masyarakat diantaranya adalah dengan aktif dalam organisasi di desa seperti karang taruna dan irmas (ikatan remaja masjid) kemudian membuat 
program kerja yang berlandaskan pada prinsip-prinsip paradigma amali, melalui pendekatan sosio-religius. Upaya penerapan moderasi beragama kepada masyarakat dapat dilakukan pula dengan menjalin kerjasama antara pihak institusi dan tokoh masyarakat sekitar dengan memanfaatkan peran Rumah Moderasi. Rumah Moderasi dapat dimanfaatkan masyarakat luas, seperti mengadakan sosialisasi tentang moderasi beragama, memudahkan masyarakat mengakses informasi mengenai moderasi beragama dan membantu menyelesaikan problematika umat beragama.

Moderasi beragama harus dipahami sebagai komitmen bersama. Menurut Edy Sutrisno, praktik moderasi beragama yang dapat diupayakan untuk masyarakat multikultural diantaranya adalah dengan menjadikan lembaga pendidikan sebagai basis penyemaian moderasi beragama dan melakukan pendekatan moderasi sosioreligius kepada masyarakat dalam kehidupaan beragama dan bernegara. Berakar dari masyarakat yang damai dan sejahtera, berbuahlah negara yang kuat dalam persatuan dan tidak akan mudah dimasuki oleh paham-paham maupun ideologi diluar ideologi bangsa, Pancasila (Sutrisno, 2019: 341). Lebih lanjut Puspo menjelaskan bahwa menjadi penting pemahaman pendidik moderat dalam membawakan ajaran agama sehingga pendidik dalam menanamkan pada anak didik bahwa keyakinan yang mereka anut tidak boleh melahirkan permusuhan, kebencian, pertentangan maupun pemaksaan dalam keyakinan agama serta dalam kehidupan berbangsa dan bernegara (Nugroho 2019:218). Secara massive Institut Agama Islam Negeri Kudus menerapkan Ilmu Islam Terapan dalam konteks paradigma amali sebagai upaya penyemaian moderasi beragama di kalangan mahasiswa. Diharapkan dengan begitu mahasiswa mampu mengaplikasikan nilainilai amali atau nilai-nilai praktis di tengah-tengah masyarakat multi religion dan multikultur. Upaya penyemaian moderasi beragama bagi mahasiswa selaku agent of change dan generasi penerus bertujuan untuk menjaga ketenangan, perdamaian dan kestabilan di tengah-tengah masyarakat.

\section{Simpulan}


Ilmu Islam Terapan menjadikan paradigma amali sebagai poin inti dari pembahasannya, yakni dengan menitikberatkan dimensi praktis di dalam kehidupan manusia. Paradigma amali mengkaji al-Qur'an, as-Sunnah dan faktualisasi Islam yang merupakan kenyataan konkret keberagamaan orang beriman. Kalam al-Qur'an dikaji secara kontekstual. Tidak hanya dipahami secara tekstual saja. Salah satu perwujudan paradigma amali adalah dengan menjalankan moderasi beragama. Moderasi agama identik dengan toleransi dan tenggang rasa. Sikap beragama yang seimbang antara keyakinan terhadap agama sendiri dan penghormatan terhadap orang lain yang berbeda keyakinan. Moderasi beragama menjadi kunci terbentuknya budaya toleransi dan kerukunan di tingkat lokal, nasional, dan global. Moderasi beragama menjadi suatu keharusan untuk Indonesia yang dihuni oleh lapisan masyarakat yang multikultural. Moderasi beragama masyarakat multikultural disebarluaskan melalui pendekatan sosio-religius.

Perguruan tinggi merupakan salah satu wadah untuk menanamkan moderasi agama agar Islam moderat dapat terwujud di Indonesia. Institut Agama Islam Negeri Kudus menghasilkan teori dan praktek mengenai moderasi agama melalui produk kerja Ilmu Islam Terapan. Adapun langkah-langkah yang dilakukan Institut Agama Islam Negeri Kudus dalam upaya menyemai moderasi beragama mahasiswa diantaranya dengan menjadikan Ilmu Islam Terapan sebagai mata kuliah ciri khas institusi, kemudian membangun Rumah Moderasi dan yang terakhir adalah dengan menyelenggarakan Kelas IIT (Ilmu Islam Terapan) bersama Prof. Muslim A. Kadir sebagai narasumber utama. Ilmu Islam Terapan harus dipahami dalam ketulusan akademik, berdasarkan pada kulliyat universalitas al-Qur'an dan as-Sunnah.

\section{Daftar Pustaka}

Akhmadi, A. 2019. Moderasi Beragama Dalam Keragaman Indonesia Religious Moderation In Indonesia's Diversity. Jurnal Diklat Keagamaan, Vol. XIII, No. 2, 45-55. 
Baedhowi, B. 2017. Islamologi Terapan Sebagai Gerbang Analog Pengembangan Islamic Studies: Kajian Eksploratif Pemikiran Mohammed Arkoun. Epistemé: Jurnal Pengembangan Ilmu Keislaman, Vol. XII, No. 2, 347-379.

Darmalaksana, W. 2019. Moderasi Beragama. Diakses Pada Tanggal 19 Mei 2020. https://uinsgd.ac.id/moderasi-beragama/

Direktorat Jendral Pendidikan Islam Kementrian Agama RI. 2020. Kemenag Siapkan Program Kerja Rumah Moderasi di PTKI. Diakses Pada Tanggal 17 Mei 2020. http://pendis.kemenag.go.id/index.php?a=detil\&id=11368

Etikasari, N.W. 2018. Persepsi Mahasiswa Program Studi S1 PPKn Universitas Negeri Surabaya Terhadap Wacana Intoleransi Di Media Sosial. Jurnal Kajian Moral dan Kewarganegaraan, Vol. VI, No. 1, 61-75.

Fhadila, K.D. 2017. Menyikapi Perubahan Perilaku Remaja Jurnal Penelitian Guru Indonesia, Vol. II, No. 2, 17-23.

Hasib, K. 2014. Studi Agama Model Islamologi Terapan Mohammed Arkoun. Jurnal TSAQAFAH, Vol. X, No. 2, 309-324.

Hermanto, M. 2016. Telaah Pemikiran Epistemologi Ilmuan Muslim Kontemporer: Perspektif Intelektual Muslim Indonesia, International Conference On Islamic Epistemology. Universitas Muhammadiyah Surakarta, 141-149.

Hiqmatunnisa, H. and Zafi, A. A. (2020) 'Penerapan Nilai-Nilai Moderasi Islam Dalam Pembelajaran Fiqih Di PTKIN Menggunakan Konsep Problem Basic Learning', JIPIS. doi: 10.33592/JIPIS.V29I1.546.

Institut Agama Islam Negeri Kudus. 2019. Pedoman Akademik Program Sarjana IAIN Kudus. Kudus: IAIN Kudus.

Kadir, M.A. 2003. Ilmu Islam Terapan (Menggagas Paradigma Amali Dalam Agama Islam). Yogyakarta: Pustaka Pelajar.

Kadir, M.A. Wawancara Oleh Nur Salamah. Institut Agama Islam Negeri Kudus. Tanggal 18 April 2020.

Kadir, M.A., Ihsan \& Muslichan, N. 2019. Kudus Kiblat Bhineka Tunggal Ika. Kudus: Forum Kerukunan Umat Beragama.

Kemenag RI. 2019. Moderasi Beragama. Jakarta: Badan Litbang Dan Diklat Kementrian Agama.

Lajnah Pentashih Mushaf Al-Qur'an Departemen Agama RI. 2012. Al-Qur'an Dan Terjemahannya Mushaf Aisyah. Jakarta: PT Insan Media Pustaka.

Mibtadin, M. 2019. Etika Dalam Diskursus Pemikiran Islam Dari Wacana Menuju Islamologi Terapan. Jurnal Suhuf, Vol. XXXI, No. 1, 89-107.

Mursyid, S. 2016. Konsep Toleransi (Al-Samahah) Antar Umat Beragama Perspektif Islam. Jurnal Aqlam, Vol. II, No. 1, 35-51. 
Nugroho, Puspo. 2012. Pendidikan Kerukunan Umat Beragama; Telaah Konsep Kerukunan Umat Beragama Perspektif Pendidikan Islam. Jurnal Mudarrisa, Vol. IV, No. 2, 299-325.

Nugroho, Puspo. 2019. Internalization of Tolerance Values in Islamic Education. Nadwa: Jurnal Pendidikan Islam 12(2): 197-228.

Purwanto, Y., Qowaid, Q., Ma'rifataini, L. \& Fauzi, R. 2019. Internalisasi Nilai Moderasi Melalui Pendidikan Agama Islam di Perguruan Tinggi Umum. EDUKASI: Jurnal Penelitian Pendidikan Agama dan Keagamaan, Vol. XVII, No. 2, 110-124.

Sahri, S.. 2016. Radikalisme Islam Perguruan Tinggi Perspektif Politik Islam. AlDaulah: Jurnal Hukum dan Perundangan Islam, Vol. VI, No. 1, 237-268.

Sutrisno, E. 2019. Aktualisasi Moderasi Beragama di Lembaga Pendidikan. Jurnal Bimas Islam, Vol. XII, No. 1, 323-348.

Yulia, Itsna. Wawancara Oleh Muhammad Arief Nugroho. Institut Agama Islam Negeri Kudus. Tanggal 20 April 2020.

Zafi, A. A. (2020). Penerapan Nilai-nilai Moderasi al-Qur'an dalam Pendidikan Islam. Jurnal Studi Ilmu-Ilmu Al-Qur'an Dan Hadis, 21(1). https://doi.org/10.14421/QH.2020.\%X

Zamimah, I. 2018. Moderatisme Islam Dalam Konteks Keindonesiaan. Jurnal Al-Fanar, Vol. I, No. 1, 75-90. 
Nur Salamah, M Arief Nugroho, Puspo Nugroho 